\title{
The effect of nitrogen source on in vitro growth of Neonectria ditissima (European canker)
}

\author{
Rebecca E. Campbell ${ }^{1, \star}$, Charles E. Chevalier ${ }^{2}$, Amandine Touron $^{2}$ and Monika \\ Walter $^{1}$ \\ ${ }^{1}$ The New Zealand Institute for Plant \& Food Research Limited, Old Mill Rd, RD3, Motueka \\ 7198, New Zealand \\ ${ }^{2}$ Ecole Nationale Supérieure d'Agronomie et des Industries Agroalimentaires (ENSAIA), \\ 2 Avenue de la Forêt de Haye, 54505 Vandoeuvre-lès-Nancy, France \\ ${ }^{*}$ Corresponding author: Rebecca.campbell@plantandfood.co.nz
}

\begin{abstract}
Nitrogen fertilisers are widely used in apple orchards. However, the effects of various nitrogen sources on growth and sporulation of the fungus Neonectria ditissima, which causes European canker, are not fully understood. The effects of various nitrogen sources commonly used in apple orchards (potassium nitrate, ammonium chloride, ammonium nitrate, ammonium sulphate, Nitrophosk $a^{\oplus}$ and urea) on percent germination and germtube growth of $N$. ditissima conidia were tested in vitro. Nitrogen concentrations below $0.2 \mathrm{~mol} / \mathrm{L}$ did not significantly affect percent conidial germination; however, concentrations above $0.2 \mathrm{~mol} / \mathrm{L}$ significantly decreased germination. Germtube growth was also affected, generally decreasing with increased N. Percent germination was influenced by the N source, but germtube growth was not. Very low concentrations of urea were indicated to stimulate germtube growth. Higher concentrations, showed toxic effects on both germination and germtube growth. The presence of exogenous $\mathrm{N}$ from various sources did not affect initial germination and growth in the $N$. ditissima infection process of apple tissues.
\end{abstract}

Keywords European canker, fertiliser, germination, germtube growth, nitrogen, Neonectria ditissima, nitrate

\section{INTRODUCTION}

Nitrogen $(\mathrm{N})$ fertilisers are commonly applied to commercial apple orchards. Too little $\mathrm{N}$ leads to poor fruit set, smaller fruit, reduced shoot growth and early leaf fall, while too much $\mathrm{N}$ can lead to reduced fruit quality, reduced tree hardiness, poor fruit colour, poor fruit storage, excess shoot growth and $\mathrm{N}$ leaching. Adding too much $\mathrm{N}$ as soil-applied fertiliser has been shown to increase apple tree vigour and in turn increase susceptibility of the tree to infection by Neonectria ditissima (syn. Nectria galligena, anamorph Cylindrocarpon heteronema; Swinburne 1975), which causes European canker (EC). Similarly, postharvest fertiliser applications of urea to tree foliage at the onset of leaf fall have caused increased leaf scar infections and European canker lesion development (Dryden et al. 2016). Both an under- and over-supply of $\mathrm{N}$ in plants have been associated with increased infections (Huber \& Watson 1974). However, information on the direct effect of fertilisers on plant pathogens is scarce (Veverka et al. 2007). Previous research has shown that high rates of nitrogen can increase populations of pests (Wermelinger et al. 1985) and incidence of many diseases (Fagard et al. 2014). Conversely, nitrogen in the form of ammonium sulphate, urea and other forms has also been used as a spray additive to increase the activity and efficacy of pesticides (Veverka et al. 2007; Siddig et al. 2013). Urea can both have a direct toxic effect on pathogens 
(Burchill 1968) and decrease the population of a pathogen by stimulating antagonistic organisms (Beresford et al. 2000; Veverka et al. 2007).

Whilst the application of manures and foliar urea dramatically increased infections of N. ditissima in apple trees (Swinburne 1975; Dryden et al. 2016), little is known of the direct effect of $\mathrm{N}$ in different forms and rates, on $N$. ditissima development. Various nitrogen sources are used in typical apple orchard management, most commonly potassium nitrate $\left(\mathrm{KNO}_{3}\right)$, ammonium chloride $\left(\mathrm{NH}_{4} \mathrm{Cl}\right)$, ammonium nitrate $\left(\mathrm{NH}_{4} \mathrm{NO}_{3}\right)$, ammonium sulphate $\left(\mathrm{NH}_{4} \mathrm{SO}_{4}\right)$, Nitrophoska $^{\circledast}$ (N-P-K, 20-12-20) and urea $\left(\mathrm{CH}_{4} \mathrm{~N}_{2} \mathrm{O}\right)$. In New Zealand, the most commonly used commercially and readily available nitrogen sources are urea, calcium ammonium nitrate $\left(\mathrm{NH}_{4} \mathrm{NO}_{3}+\mathrm{CaCO}_{3}\right)$, ammonium sulphate and Nitrophoska. The aim of this research was to investigate the direct contact effects of various nitrogen sources and their $\mathrm{N}$ concentrations on $N$. ditissima germination and germtube growth in vitro. Nitrogen in the form of potassium nitrate, ammonium chloride, ammonium nitrate, ammonium sulphate, Nitrophoska and urea at concentrations between $0-4$ moles of $\mathrm{N}$ per litre were tested. Unfortunately, calcium ammonium nitrate was unable to be tested during this experiment because when dissolved, it is cloudy and spores are unable to be seen.

\section{MATERIALS AND METHODS \\ Neonectria ditissima spore preparation}

\section{Single conidium isolates}

Preliminary experiments on fungal growth with different nitrogen sources tested three $N$. ditissima single spore isolates with known pathogenicity $($ RS305p $=$ low pathogenicity; ICMP14098 = medium; RS340p1 = high; Scheper et al. 2014). Conidia were produced under fluorescent light as described by Scheper et al. (2014); however, conidia were rinsed twice in sterile distilled water and recovered by filtering $(0.22 \mu \mathrm{m})$ using a 150 $\mathrm{mL}$ vacuum bottle filter from Biofil to remove residual nutrients from the agarous growth substrate. Spore concentrations were adjusted to $1.5 \times 10^{5}$ conidia/mL based on haemocytometer counts and stored frozen $\left(-18^{\circ} \mathrm{C}\right)$ in $1-\mathrm{mL}$ aliquots for up to 3 months (Orchard et al. 2018).

Field collected spores

Wild-type inoculum was prepared as described by Walter et al. (2015), collecting young European canker lesions from commercial 'Royal Gala', 'Scifresh' and 'Scilate' blocks in the Motueka region in spring 2017. The spore solution was again rinsed twice in sterile distilled water, adjusted to $1.5 \times 10^{5}$ spores $/ \mathrm{mL}$ using a haemocytometer and stored frozen in $1-\mathrm{mL}$ aliquots for up to 3 months.

\section{Experiment 1: Determining germination conditions}

To determine the most efficient method to measure percent germination and germtube growth, several different methods were tested, varying the size of the droplet of spore solution (5, 10 and $20 \mu \mathrm{L}$ droplets), the type of slide (concave, standard with coverslips, standard without coverslips) and spore concentration $\left(10^{4}\right.$ to $10^{6}$ conidia $/ \mathrm{mL}$ ). Germination on the slides was also compared with germination on apple sap-amended water agar (ASAWA; Amponsah et al. 2014). These glass-slide germination studies were done at $20-21^{\circ} \mathrm{C}$, in high humidity chambers (inverted agar plates) and germination assessed after $19 \mathrm{~h}$ of incubation (Scheper et al. 2014). Treatment combinations were tested in triplicate. Tests were also conducted (in triplicate) to determine whether or not spore solution in water or in the presence of exogenous micronutrients using Matsushima solution without the ammonium nitrate component (Matsushima 1961) affected the percent germination and germtube growth. Matsushima solution contains small amounts of $\mathrm{Fe}\left(\mathrm{NO}_{3}\right)_{3}, \mathrm{ZnSO}_{4}, \mathrm{MnSO}_{4}$, $\mathrm{K}_{2} \mathrm{HPO}_{4} \mathrm{MgSO}_{4}$ and $p$-hydroxybenzoic acid in $\mathrm{H}_{2} \mathrm{O}$ solution. Isolate $\mathrm{RS} 340 \mathrm{p} 1$ was used for this test. Water or Matsushima solution were also amended with 0, 0.001, 0.01, 0.1 and $1 \mathrm{~mol} \mathrm{~N} / \mathrm{L}$ of urea. Germtube length was measured for five germinated spores (per replicate droplet) using an eye-piece graticule ( $\times 100$ magnification). 
The basic assay

The basic germination assay consisted of $3 \times$ $10 \mu \mathrm{L}$ droplets $\left(10^{5}\right.$ conidia $\left./ \mathrm{mL}\right)$ on standard glass slides prepared in distilled water (wild type spores) or Matsushima broth (single spore isolates), incubated for $16-20 \mathrm{~h}$ at $20-21^{\circ} \mathrm{C}$ under high humidity (inverted agar Petri dishes). The equimolar nitrogen solutions and spore suspensions were prepared at double strength, to achieve the final concentrations when mixed 1:1. The germination tests were done for single conidia isolates and wild-type spore solutions. The percent germination was counted (up to 100 spores/droplet) and germtube growth measured for 5-10 germinated spores/droplet. There were three replicate slides of each nitrogen concentration tested, with three $10-\mu \mathrm{L}$ droplets each. Equimolar solutions were prepared to allow for direct comparison of $\mathrm{N}$ concentrations in their different chemical forms (Veverka et al. 2007). The $\mathrm{pH}$ of the nitrogen solutions up to $0.2 \mathrm{~mol} \mathrm{~N} / \mathrm{L}$ was measured for all $\mathrm{N}$ formulations. The $\mathrm{pH}$ of Nitrophoska at concentrations 0.1 and $0.2 \mathrm{~mol} \mathrm{~N} / \mathrm{L}$ was slightly elevated $(\mathrm{pH}=6.5$ and 6.7 respectively), while all other concentrations of $\mathrm{N}$ formulations were between $\mathrm{pH} 4.9$ and 5.4.

\section{Experiment 2: Germination and germtube growth for nitrogen sources $(0-0.2 \mathrm{~mol} \mathrm{~N} / \mathrm{L})$ for single conidial isolates}

For single spore isolates (RS305p, ICMP14098, and RS340p1), six nitrogen sources (urea, ammonium sulphate, ammonium chloride, ammonium nitrate, potassium nitrate and Nitrophoska) were tested at $0,0.001,0.1$ and 0.2 mol N/L. Percent germination and germtube growth were determined in Matsushima broth (without its original ammonium nitrate source) after $19 \mathrm{~h}$ incubation.

Experiment 3: Germination and germtube growth for urea $(0-2 \mathrm{~mol} \mathrm{~N} / \mathrm{L})$

For the first urea dose-response test, five concentrations of aqueous urea were used $(0$, $0.1,0.5,1,2 \mathrm{~mol} \mathrm{~N} / \mathrm{L}$ ). A spore solution from single spore isolate RS340p1 only was used. Percent germination and germtube growth were determined in distilled water after $18 \mathrm{~h}$ incubation.

\section{Experiment 4: Germination for nitrogen sources (0-4 mol N/L) for wild-type spores}

The effects of six different nitrogen sources on the germination of $N$. ditissima were tested. Urea, ammonium sulphate, ammonium chloride and ammonium nitrate were tested at $0.2,1,2$, 3 and $4 \mathrm{~mol} \mathrm{~N} / \mathrm{L}$, including a water control. It was impossible to dissolve potassium nitrate and Nitrophoska to achieve the same range of $\mathrm{N}$ concentrations as the other three chemicals, therefore Nitrophoska was tested at 0.2, 0.4, $0.7,1 \mathrm{~mol} \mathrm{~N} / \mathrm{L}$ and potassium nitrate at $0.2,0.4$, $0.7,1,1.4 \mathrm{~mol} \mathrm{~N} / \mathrm{L}$. The percent of germinated conidia was counted for each droplet after $16 \mathrm{~h}$ incubation; however, germtube growth was not measured.

\section{Statistical analyses}

The effect of germination conditions for droplet size, slide type and spore concentration (Experiment 1) was analysed using general linear model Analysis of Variance (ANOVA) in Minitab. For the nitrogen experiment (Experiment 2), the effects of different isolates, $\mathrm{N}$ concentrations and sources at low concentrations, were analysed using ANOVA using R software (v3.3.2, 2016). Percent germination and germtube growth for urea in Experiment 3 were analysed with linear models in $\mathrm{R}$, while percent germination in Experiment 4 were also plotted in $\mathrm{R}$.

\section{RESULTS}

\section{Experiment 1: Determining germination conditions}

Percent germination varied amongst treatment systems $(\mathrm{P}<0.001)$, highest on agar $(63 \%)$ followed by the standard slide $(56 \%)$, concave slide (49\%) and standard slide with cover slip (39\%). The lowest percent germination was observed for the $5 \mu \mathrm{L}$ droplet (48\%) compared with the 10 and $20 \mu \mathrm{L}$ droplets (both 53\%; $\mathrm{P}=0.009$ ). There was no interactive effect on percent germination between droplet size and slide treatment $(\mathrm{P}=0.929)$. Percent germination 
was affected by spore concentration (using the standard glass slide, $10-\mu \mathrm{L}$ droplets; $\mathrm{P}<0.001)$ with the lowest germination observed for $10^{6}$ conidia/mL (24\%) compared with $10^{5}(83 \%)$ and $10^{4}(79 \%)$ conidia/mL.

Using distilled water vs Matsushima broth for the spore suspensions did not affect percent germination ( 49 and $48 \%$, respectively; $\mathrm{P}=0.54$ ) or germtube length (26 and $27 \mu \mathrm{m}$, respectively; $\mathrm{P}=0.64$ ). When adding $0.001,0.01,0.1$ and $1 \mathrm{~mol} \mathrm{~N} / \mathrm{L}$ of urea into water or Matsushima broth, percent germination and germtube length were significantly reduced only at the highest $(1 \mathrm{M})$ urea addition $(\mathrm{P}<0.002)$. Urea at $1 \mathrm{M}$ concentration reduced germination by $31 \%$ and $38 \%$ and germtube growth by $46 \%$ and $62 \%$ in Matsushima broth and water respectively, compared with the water/broth-only controls.

In summary, $10-20 \mu \mathrm{L}$ spore droplets on flat standard glass slides, without cover slips, resulted in consistently higher percent germination than the other combinations tested. The $20-\mu \mathrm{L}$ droplets were prone to merge; therefore, the ongoing experiments were carried out using 10$\mu \mathrm{L}$ droplets on standard glass slides targeting conidia concentrations of $10^{5}$ conidia/mL prepared in either distilled water or Matsushima broth.

\section{Experiment 2: Germination and germtube growth for nitrogen sources (0-0.2 mol N/L) for single conidial isolates}

\section{Percent germination}

Overall, there was a significant difference in percent germination between isolates $(\mathrm{P}<0.001)$, with RS305p resulting in the lowest germination (35\%), followed by RS340p1 (38\%) and ICMP14098 (43\%). The nitrogen concentrations did not influence percent germination $(\mathrm{P}=0.6)$, with $39 \%, 40 \%, 37 \%$ and $39 \%$ germination at 0 , $0.001,0.1$ and $0.2 \mathrm{~mol} \mathrm{~N} / \mathrm{L}$, respectively (three isolates and six nutrients pooled). However, the type of nitrogen source had a significant effect $(\mathrm{P}<0.001)$, with the lowest percent germination seen with ammonium chloride (32\%), followed by ammonium sulphate (32\%), ammonium nitrate (35\%), Nitrophoska (42\%), urea (45\%) and potassium nitrate (46\%). There were significant interactions observed between the effects of nitrogen source and $\mathrm{N}$ concentration $(\mathrm{P}=0.02$, Fig. 1) and nitrogen source and isolate $(\mathrm{P}=0.02)$. There were no other significant interactions $(\mathrm{P}>0.5)$. For the isolate $\times \mathrm{N}$ source interaction, the low pathogenic isolate RS305p, generally had lower percent germination than the other isolates (as stated above), except in the ammonium nitrate treatment, where it had the highest germination of all isolates (39\%), and in the ammonium chloride treatment (31\%), where germination was higher than that of RS340p1 (25\%), the most pathogenic isolate. For the $\mathrm{N}$ concentration $\times \mathrm{N}$ source interaction, three $\mathrm{N}$ sources (urea, Nitrophoska, potassium nitrate) generally resulted in the same or increased percent germination with increasing $\mathrm{N}$ concentration between 0 and $0.2 \mathrm{~mol} \mathrm{~N} / \mathrm{L}$, while the other three $\mathrm{N}$ sources (ammonium sulphate, ammonium nitrate, ammonium chloride) tended to result in a decreased percent germination with increased $\mathrm{N}$ concentration (Fig. 1).

\section{Germtube growth}

Isolate RS305p had lower average germtube length $(9.6 \mu \mathrm{m})$ than isolate ICMP14098 (22.8 $\mu \mathrm{m})$ and isolate RS340p1 (26.9 $\mu \mathrm{m}$; $\mathrm{P}<0.001$ ), reflecting their known pathogenicity. Nitrogen concentrations between 0 and 0.2 mol N/L significantly affected germtube growth $(\mathrm{P}=0.025)$, with higher concentrations decreasing germtube length. Average germtube length was $20.0,20.9,16.1$, and $16.4 \mu \mathrm{m}$ for $0,0.001$, 0.1 and $0.2 \mathrm{~mol} \mathrm{~N} / \mathrm{L}$, respectively. Germtube growth, however, did not differ significantly among different nitrogen sources $(\mathrm{P}=0.59)$, ranging from 16 to $20.5 \mu \mathrm{m}$ for the six $\mathrm{N}$ sources tested. There were no significant interactions between $\mathrm{N}$ source, $\mathrm{N}$ concentration or isolate (all interactions $\mathrm{P}>0.2$ ).

\section{Experiment 3: Germination and germtube growth for urea $(0-2 \mathrm{~mol} \mathrm{~N} / \mathrm{L})$}

Percent germination decreased $\quad(\mathrm{P}<0.001$, $\left.\mathrm{R}^{2}=0.94\right)$ with increase in urea concentration (Fig. 2). Germtube length also decreased with 


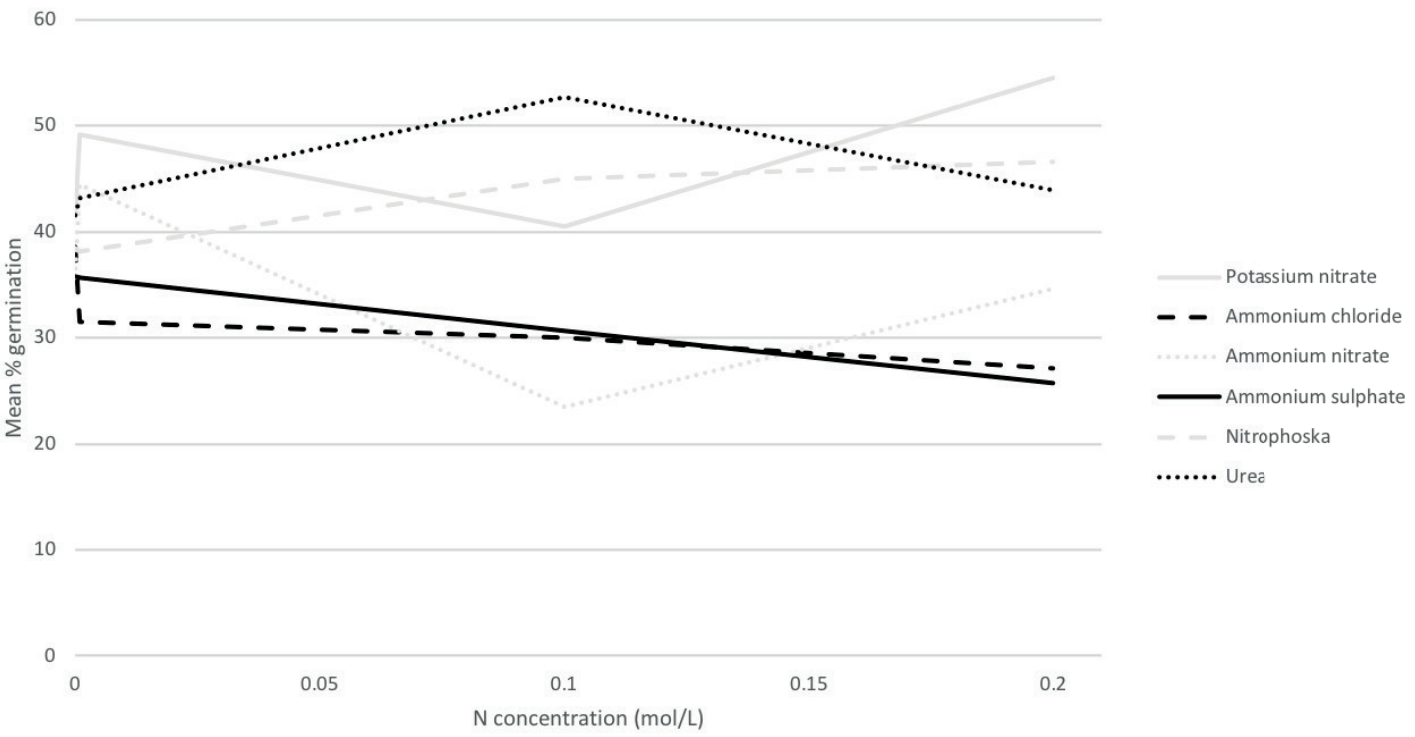

Figure 1 Percent germination for three single spore Neonectria ditissima isolates (RS305p, ICMP14098, and RS340p1 - data were pooled for the three isolates) as affected by nutrient nitrogen source and concentration. Germination was evaluated in Matsushima broth, amended with nitrogen sources tested, after $19 \mathrm{~h}$ of incubation at $20-21^{\circ} \mathrm{C}$.

increase in urea concentration (linear fit, $\mathrm{P}<0.001, \mathrm{R}^{2}=0.8$ ); however, $0.1 \mathrm{molN} / \mathrm{L}$ enhanced germtube growth slightly compared with $0 \mathrm{~mol} / \mathrm{L}$, although not statistically significant.

\section{Experiment 4: Germination of wild-type} spores for all nitrogen sources (0-4 mol N/L)

Percent germination decreased with increased $\mathrm{N}$ concentration for all nitrogen sources up to $4 \mathrm{~mol} \mathrm{~N} / \mathrm{L}$, but the decline was most apparent from $1 \mathrm{~mol} \mathrm{~N} / \mathrm{L}$. As in Experiment 3, there was a strong linear decrease in percent germination with increase in $\mathrm{N}$ concentration in the form of urea (Fig. 3a) and also for Nitrophoska, which was not continued to the higher $\mathrm{N}$ concentrations, as it could not be dissolved (Fig. 3f). The other $\mathrm{N}$ sources resulted in non-linear decreases in percent germination up to $4 \mathrm{~mol} \mathrm{~N} / \mathrm{L}$, with potassium nitrate resulting in a slightly different pattern of decay, also at lower concentrations (Fig. 3).

\section{DISCUSSION}

The direct toxic effect of nitrogen to microorganisms and insects is well known and exploited in pathogen and pest control, particularly the use of ammonia (Wermelinger et al. 1985; Beresford et al. 2000; Veverka et al. 2007; Siddig et al. 2013). It has been suggested that plants provided with either too much or too little nitrogen are also more susceptible to disease (Fagard et al. 2014; Huber \& Watson 1974). A direct toxic effect of nitrogen in its various forms $(>0.2 \mathrm{~mol} \mathrm{~N} / \mathrm{L})$ to $N$. ditissima conidia under controlled conditions was observed in vitro. It was also observed that small amounts of urea could stimulate germtube growth. Establishing biomass quickly is an important feature in the infection and disease development process of this wound pathogen, with increasing inoculum concentration decreasing the latency period (Walter et al. 2016). Additional research in our laboratory (unpublished data) has also shown that mycelial growth and conidiation can 



Figure 2 Percentage germination (a) and germtube growth (b) for Neonectria ditissima isolate RS340p1 conidia in distilled water amended with $0,0.1,0.5,1,1.5$ and $2 \mathrm{~mol}$. N/L from urea, after $18 \mathrm{~h}$ incubation at $20-21^{\circ} \mathrm{C}$. Each data point for germination rate is the mean of two counts; each data point for germtube length is the mean of 10 measurements of germinating spores. Error bars show mean \pm SE.

sometimes be enhanced at low $\mathrm{N}$ doses $(0.001$ mol N/L). The exogenous nitrogen applied in low concentrations, however, did not affect the percent germination per se, nor did exogenously applied carbon sources (unpublished data), indicating that exogenous nutrients are not required for initiation of the germination process, but are required for germtube and mycelial growth. Germtube growth was enhanced by low concentrations of $\mathrm{N}$ and this again varied amongst isolates and nitrogen sources. While germtube growth was directly correlated to order of isolates from lowest to highest known pathogenicity, the percent germination was not, indicating that differences in $\mathrm{N}$ influence on germination compared with germtube growth could be important. Furthermore, because the nitrogen formulations at the highest concentrations tested potentially vary in $\mathrm{pH}$ and osmolarity, and Nitrophoska has the addition of potassium and phosphate, these factors could be contributing to the mechanism of toxicity to $N$. ditissima. Our experiments with urea repeatedly showed a stimulus peak in germtube growth at $0.1 \mathrm{~mol} \mathrm{~N} / \mathrm{L}$, suggesting that under the conditions studied, for $\mathrm{N}$ in the form of urea, $\mathrm{N}$. ditissima growth and development was optimised. However, there were differential nitrogen source and concentration responses amongst $N$. ditissima isolates. Such differences in isolate responses to nitrogen sources and concentrations have also been reported by Veverka et al. (2007), which is why our further experiments used wildtype spores, allowing for the natural diversity in isolate responses.

There were stimulatory (mainly germtube growth) and direct toxic effects of all forms of nitrogen tested on $N$. ditissima conidia in vitro. For $N$. ditissima, the plant-pathogen interaction and the effects of nitrogen are not well understood. Unlike with Venturia inaequalis, where 5\% foliar urea applied at leaf fall supports disease control (Beresford et al. 2000), N. ditissima infections and European canker lesion development were increased by up to nine-fold with urea applied in this manner (Dryden et al. 2016).

The urea concentration tested in our study in vitro of $1 \mathrm{~mol} \mathrm{~N} / \mathrm{L}$ corresponds to approximately $6 \%$ urea solution, which is well within grower practices. However, the concentration of $0.1 \mathrm{~mol}$ $\mathrm{N} / \mathrm{L}$ corresponds to approximately $0.6 \%$ or $60 \mathrm{mg}$ urea/L, well below industry practices, while the concentrations of $24 \mathrm{~mol} \mathrm{~N} / \mathrm{L}$ are unrealistically high when used as fertilisers. From our data, we can ascertain the lethal doses toxic to $N$. ditissima for the $\mathrm{N}$ sources tested, but at those rates phytotoxicity will also be a problem. Urea is known to increase tissue damage (Wood et al. 2008) and $\mathrm{N}$ generally is known to affect cell wall breakdown. Therefore, a combination of adding vigour to the growing shoots while also potentially increasing wound size through tissue 

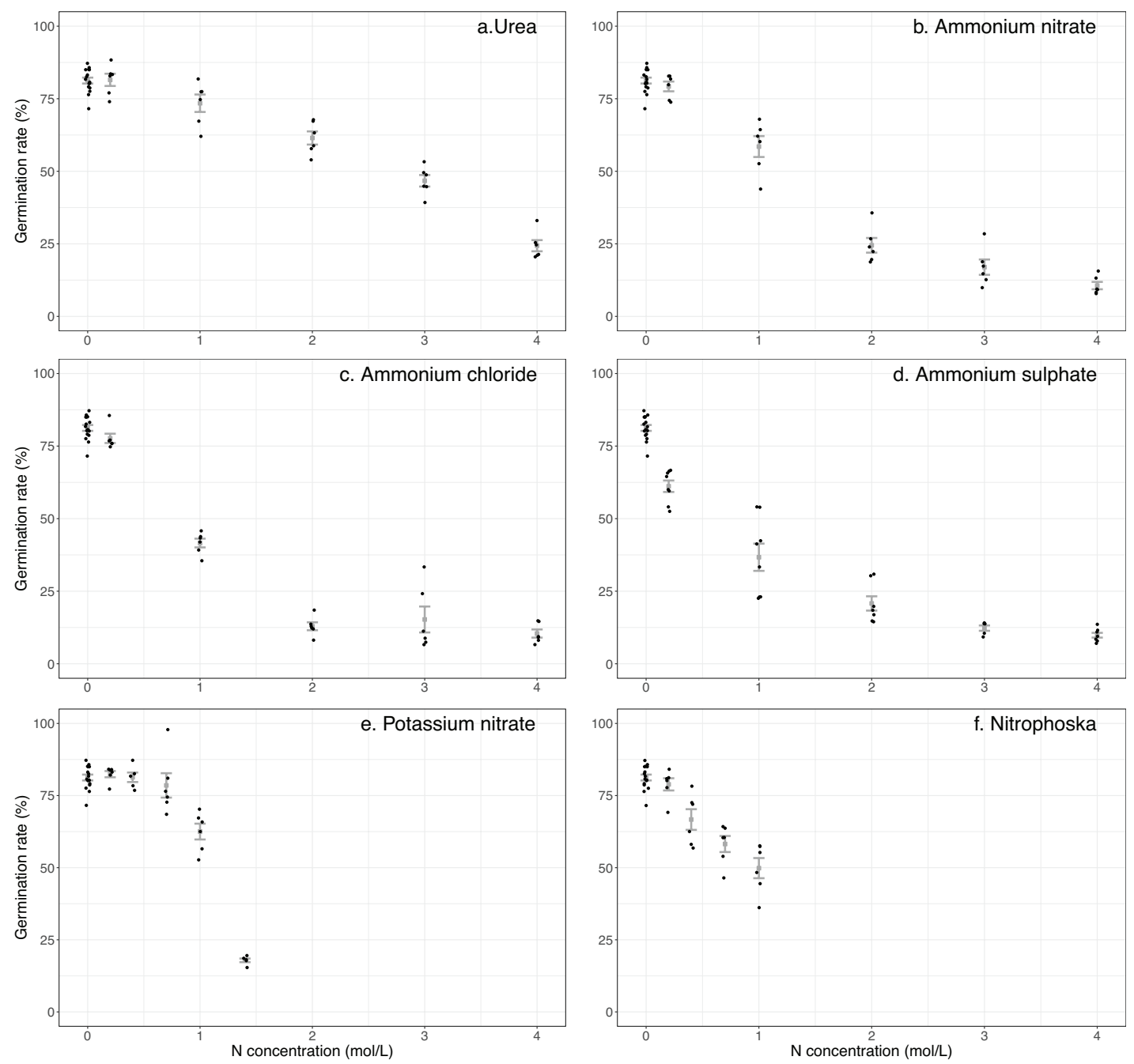

Figure 3 Percentage germination of wild-type Neonectria ditissima conidia in distilled water with varying concentrations of $\mathrm{N}$ from different sources, after $16 \mathrm{~h}$ incubation at $20-21^{\circ} \mathrm{C}$. Error bars show the mean \pm SE. Data points are offset slightly to avoid overlap of very similar values, $n=6$.

damage at leaf fall could be the main influences on increased disease in leaf scar wounds seen in the field (Dryden et al. 2016).

Excessive $\mathrm{N}$ fertilisation has been observed to stimulate development of canker (Swinburne 1975; Weber 2014) and young, vigorously growing, highly vegetative shoots may be more strongly affected by European canker than older, more slowly growing trees (Weber 2014).
Indeed, the healthiest orchards often occur where the orchardist has restricted vegetative growth by limiting $\mathrm{N}$ supply in first 3-5 years of orchard establishment (Weber 2014). There are two main nitrogen reservoirs in plants: $\mathrm{N}$ that was previously assimilated into the plant (e.g. during the season before); and stored within the trees; and newly absorbed $\mathrm{N}$ from the soil. The application of $\mathrm{N}$ fertiliser at any time in the 
season results in higher concentration of $\mathrm{N}$ in dormant shoots the next winter, increasing $\mathrm{N}$ in both xylem sap and total $\mathrm{N}$ in leaves following fertiliser application (Hill-Cottingham \& Bollard 1965). Further studies are planned to investigate how $\mathrm{N}$ concentration and transformation with plant growth can influence European canker disease in planta.

\section{CONCLUSION}

There were direct toxic effects of all forms of nitrogen tested on N. ditissima conidia in vitro. The influence of nutrients on pathogens and disease in orchards is not well understood and further studies are planned to investigate how $\mathrm{N}$ addition and transformation with plant growth can influence EC disease in planta. Responses and mechanisms can be complex because while $\mathrm{N}$ can be toxic to the pathogen, the plants response to $\mathrm{N}$ can increase its susceptibility to disease. The mechanism for the increased disease response to foliar urea application (Dryden et al. 2016), could be via physiological tree responses or indirect effects on the pathogen. This requires further study in planta.

\section{ACKNOWLEDGEMENTS}

This work was funded by The New Zealand Institute for Plant \& Food Research Limited, Strategic Science Investment Fund.

\section{REFERENCES}

Amponsah NT, Walter M, Scheper RWA 2014. Agar media for isolation of Neonectria ditissima from symptomatic and asymptomatic apple tissues and production of infective conidia. New Zealand Plant Protection 67: 116-122.

Beresford RM, Horner IJ, Wood PN 2000. Autumn-applied urea and other compounds to suppress Venturia inaequalis ascospore production. New Zealand Plant Protection 53: 382-392.

Burchill RT 1968. Field and laboratory studies of the effect of urea on ascospore production of Venturia inaequalis (Cke.) Wint. Annals of Applied Biology 62 (2): 297-307.
Dryden GH, Nelson MA, Smith JT, Walter M 2016. Postharvest foliar nitrogen applications increase Neonectria ditissima leaf scar infection in apple trees. New Zealand Plant Protection 69: 230-237.

Fagard M, Launay A, Clement G, Courtial J, Dellagi A, Farjad M, Krapp A, Soulie MC, Masclaux-Daubresse C 2014. Nitrogen metabolism meets phytopathology. Journal of Experimental Botany 65(19): 5643-5656.

Hill-Cottingham DG, Bollard EG 1965. Chemical changes in apple tree tissues following applications of fertiliser nitrogen. New Zealand Journal of Agricultural Research 8 (4): $778-787$.

Huber DM, Watson RD 1974. Nitrogen form and plant disease. Annual Review of Phytopathology, 12: 139-165.

Matsushima T 1961. A new medium for identification of hyphomycetes. Transactions of the Mycological Society of Japan 2: 118120.

Orchard S, Campbell RE, Turner L, Butler RC, Curnow T, Patrick E, Walter M 2018. Longterm deep-freeze storage of Neonectria ditissima conidium suspensions does not reduce their ability to infect apple trees. New Zealand Plant Protection 71: 158-165.

Scheper RWA, Fisher BM, Amponsah NT, Walter M 2014. Effect of culture medium, light and air circulation on sporulation of Neonectria ditissima. New Zealand Plant Protection 67: 123-132.

Siddig AA, Osman IM, Ali EM 2013. Effects of variety, nitrogen form and application timing of fungicide on early blight disease on tomato. Global Journal of Biology, Agriculture and Health Sciences 2(3): 241-248.

Swinburne TR 1975. European canker of apple (Nectria galligena). Review of Plant Pathology 54: 787-799.

Veverka K, Stolcova J, Ruzek P 2007. Sensitivity of fungi to urea, ammonium nitrate and their equimolar solution UAN. Plant Protection Science 43(4): 157-164.

Walter M, Stevenson OD, Amponsah NT, Scheper RWA, Rainham DG, Hornblow CG, 
Kerer U, Dryden GH, Latter I, Butler RC 2015. Control of Neonectria ditissima with copper based products in New Zealand. New Zealand Plant Protection 68: 241-249.

Walter M, Roy S, Fisher BM, Mackle L, Amponsah NT, Curnow T, Campbell RE, Braun P, Reineke A, Scheper RWA 2016. How many conidia are required for wound infection of apple plants by Neonectria ditissima? New Zealand Plant Protection 69: 238-245.

Weber RWS 2014. Biology and control of the apple canker fungus Neonectria ditissima (syn. N. galligena) from a Northwestern European perspective. Erwerbs-Obstbau 56: 95-107.

Wermelinger B, Oertli JJ, Delucchi V 1985. Effect of host plant nitrogen fertilization on the biology of the two-spotted spider mite, Tetranychus urticae. Entomologia Experimentalis et Applicata 38: 23-28.

Wood PN, Beresford RM, Taylor TJ 2008. Suppression of Venturia inaequalis (apple scab) ascospore production using autumnapplied fungicides. New Zealand Plant Protection 61: 54-58. 